\title{
Evaluasi Kebijakan BLT Dana Desa di Desa Sukoharjo II Kecamatan Sukoharjo Kabupaten Pringsewu
}

\author{
Beny Iswanto ${ }^{1}$ \\ ${ }^{1}$ Program Magister Ilmu Pemerintahan, Universitas Lampung \\ bramtriasmoro@gmail.com
}

\begin{abstract}
Abstrak
Dampak Covid 19 membuat pemerintahan di Desa Sukoharjo Kecamatan Sukoharjo Kabupaten Pringsewu menggelontorkan dana Desa yang seharusnya untuk pembangunan beralih menjadi BLT untuk warga yang terkena dampak covid 19. Tujuan penelitian ini yaitu untuk mengevaluasi kebijakan pemerintah Desa Sukoharjo II yang telah berlangsung. Penelitian ini menggunakan pendekatan kualitatif yaitu menggambarkan secara runtut kebijakan yang di ambil di Desa Sukoharjo II. metode pengumpulan data menggunakan metode wawancara dan dokumentasi, kemudian data yang terkumpul di analisis dengan pendekatan kualitatif. Hasilnya pemerintah Desa Sukoharjo II berhasil melakukan kebijakan telah berjalan dengan baik berdasarkan indikator evaluasi kebijakan publik dari William N Dunn, seperti efektivitas, kecukupan, pemerataan, responsivitas, dan ketepatan telah berjalan sesuai dengan peraturan pemerintah yang menetapkan calon keluarga penerima manfaat dana Desa sesuai dengan peraturan yang di keluarkan pemerintah pusat dan pemerintah daerah Kabupaten Pringsewu dengan menyingkronkan data terlebih dahulu dengan data daftar terpadu keluarga sejahtera (DTKS) dari Dinas Sosial.
\end{abstract}

Kata kunci : Dana Desa, Dampak Pandemi, Evaluasi Kebijakan.

\begin{abstract}
The impact of Covid 19 made the government in Sukoharjo village, Sukoharjo sub-district, Pringsewu regency, pour out village funds that should have been converted into BLT for residents affected by covid 19 . The purpose of this study is to evaluate the policies of the Sukoharjo II village government that have been ongoing. This study used a qualitative approach, namely describing the policies adopted in the village of Sukoharjo II coherently. data collection methods using interviews and documentation, then the data collected is analyzed with a qualitative approach. The result is that the Sukoharjo II village government has succeeded in carrying out policies that have been running well based on indicators of evaluation of public policies from William N Dunn, such as effectiveness, adequacy, equity, responsiveness, and accuracy have been running in accordance with government regulations that determine potential family beneficiaries of village funds in accordance with regulations. issued by the central government and the regional government of Pringsewu Regency by synchronizing the data in advance with the integrated list of prosperous families (DTKS) from the Social Service Agency.
\end{abstract}

Keywords : Impact of Pandemic, Village Fund Assistance, Policy Evaluation. 


\section{Pendahuluan}

Pada tanggal 31 Desember Badan Kesehatan Dunia atau WHO mengonfirmasikan masalah kesehatan dunia yaitu dengan ditemukanya adanya kasus kluster pneumonia dengan etiologi yang terjadi di Kota Wuhan Provinsi Hubei, China. Laproan kematian atas kasus ini terus berkembang hingga menyebabkan importisasi di China. Kemudia pada tanggal 12 Februri 2020 WHO secara resmi menetapkan jenis penyakit novel coronavirus terhadap manusia ini dengan nama coronavirus disease atau yang sering disebut dengan (Covid-19) dan WHO sudah menetapkan covid-19 sebagai pendemi. Di Indonesia kasus pertama covid-19 muncul pada tanggal 2 Maret 2020 dengan adanya laporan 2 kasus konfirmasi covid-19. Adanya temuan kasus covid-19 di Indonesia inilah yang menjadi awal kebijakan pemerintah dengan menereapkan lock down di seluruh Indonesia (Maun, 2020 ).

Hadirnya pandemic covid-19 meberikan pengaruh terhadap seluruh sektor masyarakat Indonesia, misalkan sektor pendidikan yang terkena dampak dengan penerapan lockdown mengharuskan siswa dari tingkat SD, SMP, SMA/SMK dan Mahsiswa yang tidak bisa melakukan pembelajaran tatap muka dan dihimbau untuk melakukan pembelajan melalui daring (pembelajaran online). Dari sektor transportasi para diriver ojek online tidak bisa lagi mengantarkan penumpang melainkan hanya mengantarkan pesananan berupa barang saja. Dan di sektor ekonomi juga terkena dampak dengan mulai sepimya pertokoan dari minat pembeli, dan hilangnya pekerjaan karena di PHK ole perusahaan. Pandemic covid-19 juga memukul sektor pariwisata karena tidak bisa melakukan perjalanan dari luar daerah dan himbauan untukk dirumah saja juga tidak sedikit menjadi pukulan di seluruh sektor yang terbiasa dengan pekerjaan di luar dan kerumunan orang banyak.(Mufida, 2020 )

Dampak dari pandemi ini sendiri bagi keberlangsungan hidup orang banyak menimbulkan kesenjangan yang terjadi di masyarakat. Banyak orang yang kehilangan mata pencaharian dari adanya covid-19 dan menambah angka pengangguran yang menyebabkan banyak kantor atau buruh pabrik yang memberhentikan tenaga kerja akibat dampak dari covid-19. 
Pandemi Covid-19 adalah suatu masalah yang sangat penting ditahun 2020 ini karena karena beerdampak langsung kepada masyarakat di berbagai sektor. Hadirnya bencana covid-19 menyebabkan pemerintah harus menggelontorkan bantuan untuk masyarakat baik pemerintah pusat, provinsi, kabupaten atau kota bahkan sampai kepada pemerintah Desa untuk menggelontorkan bantuan kepada masyarakat akibat adanya wabah covid-19 yang mengguncang Indonesia. Untuk mengatasi dampak pandemi covid-19 dan upaya pemulihan ekonomi ditingkat Desa maka pemerintah melakukan kebijakan yang strategis. Kebijakan tersebut yaitu dengan memprioritaskan penggunaan dana Desa dan memberikan stimulus bantuan penanganan covid-19 sesuai PermenDesa PDTT 7 Tahun 2020 tentang Prioritas Penggunaan Dana Desa Tahun 2020 untuk menangani pandemi covid-19 dan program-program kegiatan pembangunan dengan sistem padat karya tunai atau swakelola (Ayu, Siahainenia, \& Kudubun, 2020). Dana Desa merupakan instrumen untuk menjadikan masyarakat yang makmur dan sejahtera, setelah pandemi covid19 menyerang dan kebutuhan terus membengkak mengakibatkan masalah baru di Desa.

Dasar juridis dan implementatif Bantuan Langsung Tunai (BLT) kepada penduduk miskin di Desa yaitu dengan terbitnya Peraturan Menteri Desa dan Pembangunan Daerah Tertinggaldan Transmigrasi (Permendes PDTT) Nomor 6 Tahun 2020 tentang Perubahan Atas PeraturanMenteri Desa, Pembangunan Daerah Tertinggal, dan Transmigrasi Nomor 11 Tahun 2019tentang Prioritas Penggunaan Dana Desa Tahun 2020. Berdasarkan peraturan diatas makaguna menanggulangi dampak dari adanya pandemi global tersebut pemerintah daerah Kabupaten Pringsewu membuat sebuah kebijakan untuk membantu masyarakat dengan memberikan bantuan BLT dana Desa untuk keluarga terdampak covid-19 dengan Nomor: 142/254/D.10/2020. Surat Bupati Pringsewu tersebut di tujukan kepada seluruh Camat dan Kepala Desa di Kabuapaten Pringsewu yang menjadi dasar dan pedoman dalam mendata calon keluarga penerima Bantuan Langsung Tunai (BLT) dana Desa.

Salah satu keunggulan dana Desa yaitu alokasi anggaran tersedia dalam Anggaran Pendapatan dan Belanja Negara; bisa digunakan untuk membangun 
legitimasi dan kredibilitas pemerintah Desa melalui penyelesaian masalah secara lokal; bisa juga sebagai program aksi cepat yang dapat segera dimulai; bisa menjadi pelengkap program lain supaya meminimalkan dampak sosial dan ekonomi; tidak membutuhkan sistem baru jadi aparat Desa bisa langsung bergerak sebab sudah memahami sistem yang ada; kemudian sudah tersedianya sistem pemantauan, evaluasi, dan pertanggungjawaban yang dapat dioptimalkan untuk menjamin akuntabilitas. Dana Desa adalah alokasi anggaran on budget yang dapat digunakan langsung untuk mendukung sebagai upaya mengurangi dampak Covid-19 di tingkat rumah tangga dan Desa (Maun, 2020).

Pekon/Desa Sukoharjo II Kecamatan Sukoharjo Kabupaten Pringsewu adalah Pekon/Desa yang warganya terkena dampak langsung dari pandemi covid19. Dengan terbitnya surat keputusan Bupati Kabupaten Pringsewu maka pemerintah pekon/Desa Sukoharjo II khususnya Kepala Pekon/Desa segera mungkin untuk membuat pendataaan calon keluarga penerima bantuan langsung tunai atau (BLT) dana Desa atau (DD) sesuai dengan ketetapan bupati Kabupaten Pringsewu.

Berbagai syarat calon keluarga penerima manfaat yang berhak menerima BLT Desa adalah kehilangan mata pencaharian, belum terdata dan mempunyai penyakit kronis. Selain itu akan mempertimbangkan Data Terpadu Keluarga Sejahtera atau (DTKS) dari Kementerian Sosial (Kemensos), dan juga diupayakan bahwacalon penerima bantuan langsung tunai BLT dana Desa ini tidak termasuk ke dalam penerima bantuan Program KeluargaHarapan (PKH), bantuan pangan non tunai (BPNT), Bantuan setoran Tunai (BST kementrian Sosial melalui kantor pos) dan Kartu Prakerja serta bantuan dari dinas ketehanan pangan.

Pendataan sendiri dilakukan oleh Kasi Kesra, Kadus, RT, PSM, kemudian di tentukan dalam musyawarah khusus, yang telah di verifikasi, validasi dan keputusan akhir penetapan calon keluarga penerima manfaat bantuan langsung tunai (BLT) dana Desa di buatkan berita acara yang di tanda tangani oleh kepala pekon/Desa Sukoharjo II dan Ketua BHP atau (BPD). Dan usulan tersebut di setorkan ke camat untuk disampaikan kepada bupati meluli dinas Pemberdayaan Masayarakat Desa (PMD). 
Metode penyaluran untuk penerima bantuan langsung tunai dana Desa dilakukan oleh pemerintahanpekon/Desa dengan metode non tunai (cash less) langsng ke rekening keluarga penerima manfaat BLT dana Desa dengan menggunakan Bank BRI sebagai mitra. Dana yang diterima keluarga penerima manfaat bantuan langsung tunai (BLT) dana Desa Sukoharjo II yaitu Rp. 600.000 untuk 3 Bulan pertama, yaitu April, Mei Juni, Kemudian Rp.300.000 untuk bulan Agustus-Desember.

Kebijakan yang di ambil Kepala pekon/Desa Sukoharjo II, merupakan sebagai kepanjangan tangan dari pemerintah pusat untuk dapat menggunakan dana Desa untuk penanggulangan bencana pandemic covid-19 untuk mengurangi tanggungan warga masyarakat yang terkena dampak. Kebijakan public adalah sebuah proses yang diambil pemerintah untuk tujuan melaksanakan tugas-tugas pemerintahannya, hasil dari proses politik yang berjalan pada penyelenggaraan negara. kemudian menurut Wiliiam N. Dunn "tahap-tahap kebijakan publik meliputi penyusunan agenda, formulasi kebijakan, adopsi/legitimasi kebijakan, dan penilaian/evaluasi kebijakan". Evaluasi kebijakan digunakan sebagai alat melihat sejauh mana kebijakan yang diambil telah mampu memecahkan permasalahan dan memberikan dampak sesuai yang diharapkan. Evaluasi kebijakan dilakukan dalam seluruh tahapan kebijakan, tidak hanya dilakukan pada tahap akhir saja (Kurnia \& Widhiasthini, 2021).

Sebagai suatu kegiatan yang fungsional maka evaluasi kebijakan dipandang sebagai suatu prses tahapan yang harus ada dalam setiap tahapan. Artinya, seluruh proses kebijakan baik itu dari proses awal hingga proses akhir harus selalu melewati proses evaluasi kebijakan untuk mengambil sebuah keputusan atau penilaian. kemudian, evaluasi kebijakan dibedakan ke dengan dua tugas yang bermacam, yaitu: (a) untuk menggambarkan dampak yang di timbulkan oleh suatu kebijakan serta konsekuensi yang akan di dapatkan dari suatu kebijakan, dan (b) menetapkan kriteria dan standar untuk menilai keberhasialan dan kegagalan pada suatu kebijakan (Sartika, 2011).

Telah banyak studi yang membahas penelitian mengenai evaluasi kebijakan dan dana Desa evaluasi kebijakan padat karya tunai untuk pemberdayaan 
di Desa (Kurnia \& Widhiasthini, 2021), penggunaan dana Desa untuk penanggulangan covid-19 (Ayu, Siahainenia, \& Kudubun, 2020), Efektivitas program Dana Desa (Maun,2020), serta polemik dengan dikeluarkannya bantuan sosial ke masyarakat salah satunya yaitu kriteria penetapan BLT dana Desa yang hampir mirip dengan bantuan sosial yang dikeluarkan oleh kementerian sosial (Mufida, 2020). Namun masih sedikit yang membahas evaluasi kebijakan bantuan langsung tunai (BLT) dana Desa akibat pandemi Covid 19. Sehingga studi ini akan lebih memfokuskan mengenai evaluasi kebijakan Bantuan Langsung Tunai (BLT) dana Desa di Pekon/Desa Sukoharjo II Kecamatan Sukoharjo Kabupaten Pringsewu dengan menggunakan konsep evaluasi kebijakan Wiliam N Dunn, menggunakan indikator seperti efektivitas, responsivitas, pemerataan, kecukupan dan ketepatan.

Berdasarkan pada penjabaran latar belakang permasalahan di atas, penulis melakukan penelitian tentang evaluasi kebijakan bantuan langsung tunai (BLT) dana Desa di Desa Sukoharjo II. Adapun tujuan yang diharapkan dalam penelitian ini yaitu untuk mengetahui program BLT di pekon/Desa Sukoharjo II sudah berjalan dengan baik atau belum dan mengetahui dampak yang ditimbulkan oleh kebijakan tersebut.

\section{Metode}

Pada penelitian ini penulis menggunakan pendekatan deskriptif kualitatif. Yaitu suatu model penelitian dengan menggambarkan secara rinci mengenai data, informasi, kejadian-kejadian secara sistematis, faktual dan akurat dengan menggunakan data berupa kata-kata atau pernyataan dari seseorang (Sugiyono, 2010). Pada penelitian ini penulis berusaha menggambarkan mengenai evaluasi kebijakan bantuan langsung tunai dana Desa di pekon/Desa Sukoharjo II. Kemudian untuk melengkapi kebutuhan data dan informasi dari suatu kejadian kebijakan yang di ambil oleh pemerintah pekon/Desa sukoharjo II ada beberapa teknik pengumpulan data yang digunakan untuk melengkapi penelitian tersebut (Sugiyono, 2010).Teknik pengumulan data yang digunakan yaitu dengan menggunakan teknik obeservasi, wawancara, dan dokumentasi. Analisis data dilakukan melalui pengumpulan data, setelah itu data yang telah diperoleh 
dilakukan reduksi data. Selanjutnya dilakukan penyajian data dan pengambilan kesimpulan.

\section{Hasil dan Pembahasan}

\section{Potret Penyaluran BLT Dana Desa di Desa Sukoharjo II}

Pekon adalah sebutan Desa yang di pakai di Kabupaten Pringsewu, dan Pekon/Desa Sukoharjo II merupakan sebuah pekon/Desa yang terletak di Kabupaten Pringsewu Provinsi Lampung. Sebagai sebuah Desa yang juga terdampak akibat adanya pandemi Global Covid-19 maka sebagai ujung tombak dari pemerintah maka Kepala Desa Sukoharjo II menjalankan anjuran dari pemerintah Pusat serta daerah untuk menggunakan dana Desa tersebut sebagai bentuk bantuan langsung tunai (BLT) yang diperuntukkan bagi masyarakat atas dampak dari pandemic covid-19. BLT Dana Desa merupakan dana yang seharusnya diperuntukkan bagi pembangunan dan pengembangan Desa kemudian dialihkan menjadi dana bantuan tunai.

Sebelum penggunaan BLT dana Desa di peruntukan akibat wabah covid19 program tersebut sudah pernah di lakukan juga di Indonesia yaitu ketika adanya kenaikan BBM. Pemberian sejumlah uang ataupun dana tunai untuk masyarakat kurang mampu setelah diputuskan oleh pemerintah bahwasannya terjadi kenaikan harga BBM salah satunya dengan mengurangi subsidi namun selisih dari subsidi tersebut diperuntukkan bagi masyarakat kurang mampu dapat dikatakan dengan BLT.

Berbeda dengan agenda BLT sebelumnya bantuan ini diberikan dengan menggunakan kualifikasi dan pendataan yang ketat sesuai dengan surat keputasan Bupati Kabupaten Pringsewu dan dari Dinas Sosial Kabupupaten Pringsewu bahwa BLT deberikan untuk kelompok yang rentan terdampak covid-19, dengan kualifikasi, keluarga miskin yang terdapat dalam Data Terpadu Kesejahteraan Sosial Keluarga Non PKH/BPNT, kehilangan mata pencaharian, belum terdata serta memiliki riwayat penyakit kronis maupun menahun.

Mekanisme pendataan dilakukan oleh perangkat Desa, dan di bantu oleh Pekerja Sosial Masyarakat (PSM), Tenaga Kerja Sosial Kecamatan 
(TKSK),)Puskesos serta Pendampung PKH sesuai dengan surat tugas yang di keluarkan oleh Kepala Desa Sukoharjo II. sebelum menentukan keluarga penerima BLT Dana Desa terlebih dahulu di verifikasi keluarga yang telah mendapatkan bantuan PKH/ BPNT, Keluarga Penambahan BPNT dan Bantuan Sosial Tunai dari dinas Sosial dan berikut daftar tabel pendataan awal yang dilakukan dengan jumlah KK yang ada di Desa Sukoharjo II sebanyak 890 KK, terdiri dari 4 RW dan 12 RT.

Tabel 1. Jumlah Keluarga Penerima Bantuan

\begin{tabular}{|l|l|l|}
\hline No & Jenis Bantuan & Jumlah \\
\hline 1. & BPNT RASTA PKH & 151 \\
\hline 2. & BPNT RASTA NON PKH & 65 \\
\hline 3. & Perluasan BPNT & 141 \\
\hline 4. & BST & 105 \\
\hline 5. & BLT DD & 171 \\
\hline
\end{tabular}

Sumber : Pemerintah pekon/Desa Sukoharjo 2020.

Setelah penetapan keluarga yang diusulkan oleh ketua RT dan RW kemudian nama-nama keluarga penerima bantuan BLT Dana Desa di musyawarahkan bersama dengan Badan Pemusywaratan Desa dalam acara Musyawarah Desa Khusus (Musdesus) untuk memverifikasi, memvalidasi dan memfinalisasi usulan penerima bantuan tersebut untuk kemudian disetujui Kepala Desa serta Badan Permusyawaratan Desa sebagai keluarga yang menerima bantuan tersebut.

Kebijakan yang di ambil oleh Kepala Desa Sukoharjo II dengan mempertimbangkan validasi diatas maka keputusan yang di ambil Kepala Desa Sukoharjo II yaitu 171 KK sebagai penerima BLT Dana Desa. Penyaluran dilakukan dengan mekanisme Non Cash yaitu dengan cara mentransfer ke rekening BRI penerima Bantaun Langsung Tunai. Dan penerima bantuan pun dibuatkan rekening dan ATM BRI kepda penerima bantuan. Bantuan yang diberikan terhitung April Mei Juni dengan besaran uang yaitu Rp.600.000. Kepala Desa sebagai pemegang kekuasaan di tingkat Desa dengan mempertimbangkan surat keputusan pemerintah pusat dan daerah juga mengeluarkan kebijakan public yang berguna dan 
membantu kepentingan orang banyak sebagai dampak dengan adanya covid-19 yakni dengan pemberian BLT yang sumber utamanya dari dana Desa.

\section{Evaluasi Kebijakan BLT Dana Desa di Desa Sukahorjo II}

Kebijakan publik adalah sesuatu tindakan yang dikerjakan atau tidak dikerjakan oleh pemerintah. Kebijakan publik juga tidak bisa memuaskan semua orang, karena pasti ada pihak yang dirugikan dan diuntungkan dalam sebuah kebijakan publik. Kebijakan publik juga harus mengandung manfaat bersama bagi warganya dan menimbulkan dampak kerugian sekecil mungkin bagi warga masyarakatnya. Kebijakan harus menjadi pertimbangan bersama supaya kebijakan tersebut berhasil dan menguntungkan masyarakat, selain itu kebijakan tersebut harus mengandung kebijaksanaan oleh pemerintah agar kebijakan yang dibuat sesuai yang diharapkan dan pemerintah harus bijaksana dalam menetapkan suatu kebijakan agar tidak salah langkah (Taufiqurkhman, 2014).

Tahap akhir dalam formulasi kebijakan ialah evaluasi kebijakan, evaluasi kebijakan ada bebeapa tahapan dalam menentukan evaluasi di antaranya sebagai berikut:

1. evaluasi awal yaitu sebuah evaluasi di tahap awal sebelum tahapan pelaksanaan di tetapkan dan di laksananakan

2. Evaluasi dalam proses implementasi

3. Evaluasi akhir yaitu sebuah pelaksanaan yang dilakukan karena proses pelaksanaan telah selesai dilakukan (Ikbal, 2015)

Kegiatan mengukur suatu kebijakan apakah berhasil ataupun gagal berlandaskan pada indikator yang telah ditetapkan disebut Evaluasi Kebijakan Publik. Terdapat dua aspek pada Indikator evaluasi kebijakan yakni proses dan hasil. Kebijakan berhasil atau gagal dinilai dari indikator-indikator yang telah dikembangkan. Pendekatan yang peneliti gunakan yakni dari William N Dunn dengan pengembangan lima indikator atau kriteria evaluasi yang mencakup sebagai berikut (Subarsono, 2011) :

\begin{tabular}{|l|l|l|}
\hline No & Kriteria & Penjelasan \\
\hline 1 & Efektivitas & Apakah tujuan yang diharapkan telah tercapai? \\
\hline 2 & Kecukupan & $\begin{array}{l}\text { Apakah tujuan yang diharapkan bisa menyelesaikan } \\
\text { masalah? }\end{array}$ \\
\hline
\end{tabular}




\begin{tabular}{|l|l|l|}
\hline 3 & Pemerataan & $\begin{array}{l}\text { Apakah biaya dan manfaat didistribusikan merata } \\
\text { terhadap kelompok masyarakat lain? }\end{array}$ \\
\hline 4 & Responsivitas & $\begin{array}{l}\text { Apakah hasil kebijakan mendapatkan nilai dan } \\
\text { preferensi kepada masyarakat? }\end{array}$ \\
\hline 5 & Ketepatan & $\begin{array}{l}\text { Apakah hasil yang diharpkan bermanfaat bagi } \\
\text { masyarakat? }\end{array}$ \\
\hline
\end{tabular}

\section{a. Efektivitas}

Taraf tercapainya suatu tujuan tertentu, hak ditinjau dari segi hasil, maupun usaha dari segi usaha yang diukur disebut efektivitas. Maun (2020) bahwa tingkat efektivitas bisa dikatakan berhasil apabila suatu yang diukur sesuai dengan rencana yang telah ditargetkan. Apabila rencana tersebut tidak sesuai dengan apa yang telah ditargetkan maka bisa dikatakan program atau kebijakan tersebut tidak efektif.

Adanya kriteria oleh pemerintah pusat dalam penentuan keluarga penerima manfaat BLT dana Desa kebijakan tersebut sangat efektif. Tujuan yang ingin dilakukan yaitu membantu warga Desa sukoharjo II yang terkena dampak dari pandemic covid-19.Dengan keadaan ekonomi yang sulit di masa pandemic khususnya bagi para pelaku usaha yang kehilangan mata pencaharian akibat adanya pandemic covid-19 bantuan BLT dana Desa dirasa sangat membantu sekali kepada para warga. Berdasarkan temuan peneliti keluarga penerima bantuan dirasa sangat membantu dalam menambah uang sehari-hari untuk keperluan keluarga, dimana jika di hari-hari biasa ia bisa bekerja berjualan di sekolah namun semenjak adanya pandemic keluarga tersebut tidak ada pemasukan. Pemberian BLT merupupakan kebijakan yang efektif karena dapat menyentuh langsung keluarga yang terkena dampak tersebut, terlebih wewenang dan pemilihan keluarga di serahkan sepenuhnya kepada pemerintah Desa dengan proses validasi yang ketat. Dan tujuan dari BLT dana Desa sendiri untuk membantu masyarakat miskin, kehilangan mata pencaharian sangat efektif dan membantu mereka. Dengan uang Rp. 600.000 dari bulan April sampai Juni cukup untuk membantu keluarga di Desa Sukoharjo II sebagai dampak dari adanya covid-19. Hasilnya para warga pun sangat antusias dengan kebijakan tersebut, dan merasa dirinya dibantu oleh pemerintah di masa yang serba sulit karena kehilangan pekerjaan dan lain sebagainya. 


\section{b. Kecukupan}

Kecukupan dapat diartikan sebagai suatu tujuan yang telah tercapai dan dirasakan dalam menjawab permasalahan yang ada. Tujuan dari pemerintahpekon/Desa Sukoharjo II dengan menyalurkan bantuan langsung tunai dana Desa yaitu untuk membantu dan mengurangi beban yang di terita oleh warga masyarakat Sukoharjo II karena adanya pandemic covid-19. Dengan adanya pandemi covid-19 Bantuan Langsung tunai (BLT) dana Desa jika dilihat dari segi kecukupan dengan besaran uang Rp.600.000 antara bulan April sampai Juli dalam hasil penelitian yang di temukan di lapangan uang sebesar Rp.600.000 bagi warga penerima manfaat bisa langsung dirasakan oleh warga masyarakat. Besaran uang pun langsung di kirim ke rekening masing-masing masyarakat yang mendapatkan bantuan tersebut tanpa pemotongan oleh pemerintah pekon/Desa maupun petugas Bank. Menurut pengakuan seorang warga bantuan yang diberikan oleh pemerintah ini sudah sangat membantu dan sedikit meringankan beban keluarganya.

\section{c. Pemerataan}

Pemerataan yaitu suatu keadilan yang diperoleh dan diberikan dari sebuah kebijakan publik. Pemerataan merupakan sebuah indokator dalam kebijakan public yang menuntut pemerintah untuk berlaku seadil-adilnya tanpa harus memandang keluarga dan kerabat dalam memberikan bantuan. Pemerintah Desa dan tim verifikasi sebelum menentukan keluarga penerima manfaat dana Desa mereka melakukan keputasan tersebut bedasarkan data dengan DTKS Desa Sukoharjo II untuk di sinkronkan dengan keluarga yang sudah menerima BPNT/PKH, BPNT Non PKH, perluasan BPNT dan BST dinas sosial yang pengambilan bantuanya dari dinas sosial serta bantuan sosial lainyaseperti sembako, kebutuhan pangan dan lain sebagainya bagi warga yang belum tercover bantuan sama sekali. Dengan mempertimbangkan data tersebut maka jumlah KK yang ada di Desa Sukoharjo II yaitu sebesar 890 dikurangi 462 sehingga hanya tersisa 428 keluarga yang menjadi prioritas penerima bantuan BLT DD.

Mengingat anggaran DD yang di terima Desa Sukoharjo II tidak bisa memberikan semuanya kepada warga Desa maka yang ada dalam Desa di tetapkan keluarga penerima manfaat dana Desa sebesar $171 \mathrm{KK}$ sesuai kempuan anggaran 
dana Desa. Kebijakan tersebut dirasa sangat adil oleh para warga Desa sukoharjo II, karena banyak keluarga yang merasa iri kepada mereka para penerima bantuan BPNT dan PKH yang setiap bulanya mendapatkan beras, sementara warga yang menerima bantuan BLT dana Desa baru sekali ini merasa dibantu oleh pemerintah lewat kebijakan BLT dana Desa. Jika dilihat dari indikator pemerataan kebijan tersebut sangat merata karena pemilihan dan validasi data di lakukan oleh pemerintah Desa di bantu dengan PSM, Puskesos dan para RT yang mengetahui warga-warga mana saja yang di rasa sangat membutuhkan bantuan.

\section{d. Responsivitas}

Responsivitas merupakan respon dari suatu kebijakan publik/aktivitas atau bisa dikatakan seberapa jauh respon pemerintah dalam menjawab sebuah permasalahan yang timbul dalam suatu masyarakat. Respon pemerintah pekon/Desa dalam menghadapi masalah tersebut yaitu dengan memberikan bantuan BLT yang bersumber dari dana Desa kepada warga yang terdampak akibat dengan adanya pandemic covid-19. Kebijakan ini pun disambut dengan sangat baik oleh waega masyarakat pekon/Desa Sukoharjo II setidaknya dengan bantuan tersebut dapat meringankan beban perekonomian warga. Dengan adanya bencana global tersebut membuat warga pwkon/Desa Sukoharjo II banyak warga yang terkena dampak akibat wabah yang berasal dari Wuhan China tersebut. Ada warga yang tidak bisa berjualan, menutup usahanya, sampai dengan program PHK. Maka kebijakan tersebut sangatlah dibutuhkan mengingat mereka tidak bisa berbuat apaapa selain mengharapkan bantuan dari pemerintah.

\section{e. Ketepatan}

Ketepatan yaitu merujuk kuatnya sebuah asumsi yang menjadi dasar tujuan tersebut. Secara keseluruhan dampak positif yang dihadirkan dalam implementasibantuan BLT dana Desa ini telah dapat dirasakan manfaatnya langsung oleh warga masyarakat Pekon/Desa Sukoharjo II. Yang mana masyarakat memperoleh bantuan uang akibat dari dampak adanya pandemi covid-19 untuk kelangsungan hidup keluarga sehari-hari.

Kebijakan yang telah diambil oleh pemerintah pekon/Desa Sukoharjo II merupakan sebuah kewajiban yang harus dilaksanakan oleh seluruh pemerintahan 
Desa, prioritas tersebut diambil guna menanggulangi dampak dari covid-19 yang ada di Desa. Tahapan evaluasi yang digunakan pemerintahan Desa/pekon Sukoharjo telah dilakukan dari mulai awal hinga akhir penetapan penerima BLT. Evaluasi awal dilakukan oleh seluruh pemerintahan pekon/Desa Sukoharjo II untuk membahas tahapan awal yang akan dilakukan dari kebijakan yang telah di ambil pemerintah Kabupaten Pringsewu melalui surat edaran Bupati untuk menetapkan langkah yang akan di ambil dengan melihat dana Desa yang tersedia di pekon/Desa Sukoharjo II. Evaluasi tahapan implementasi atau pelaksanaan dilakukan pemerintah pekon/Desa Sukoharjo II dengan tim verifikasi untuk menetapkan nama kepada calon penerima BLT. Tahapan akhir yang dilakukan yaitu evaluasi tahap akhir setelah pelaksanaan dilakukan dengan guna mengevaluasi keluarga penerima BLT tahap pertama untuk dievaluasi bersama untuk penyusunan ke depan namanama yang menerima bantuan, apakah sudah sesuai dengan criteria atau belum, dan untuk bahan acuan pengurangan/penghapusan untuk tahapan selanjutnya.

Berdasarkan hal tersebut tahapan evaluasi mulai dari awal hingga akhir sudah sesuai dengan tahapan evaluasi kebijakan, evaluasi kebijakan yang dilakukan merupakan sebuah wadah bersama untuk tidak salah langkah dalam menentukan keluarga penerima BLT supaya tepat sasaran. Hal ini penting untuk dilakukan dalam setiap instansi pemerintahan terutama di pekon/Desa untuk selalu mengikuti tahapan evaluasi karena dengan tahapan ini yang sudah terlewati maka setiap kebijakan dapat berjalan dengan baik.

Berbeda dengan temuan penelitian yang dilakukan oleh (Ikbal, 2015), tentang evaluasi kebijakan penertiban ternak di Kecamatan Parigi belum memberikan hasil yang maksimal, hal ini dapat terlihat dari masih banyaknya hewan yang berkeliaran di lingkungan masyarakat. Hal ini karena kurangnya sosialisasi kegiatan penertiban dan belum adanya alokasi dana operasional. Sementara dalam penelitian ini sudah semua aspek kebijakan sudah dilakukan baik peraturan sosialisasi, dan alokasi dana operasional yang sudah tersusun rapih baik regulasi pusat, daerah dan pemerintahan Desa. Dalam tahapan pelaksanaan pun dilakukan secara terus menerus dan merupakan kesepakatan bersama. 
Tahapan penilaian evaluasi kebijakan publik BLT dana Desa di Sukoharjo II dengan memperhatikan indikator dari Wiliam N Dunn tentang indikator penilaian dengan tahapan evaluasi kebijakan publik yang diukur dengan menggunakan 5 kriteria yaitu efektivitas, kecukupan, ketetapan, pemerataan, kecukupan. Berdasarkan hal tersebut maka dapat disimpulkan bahwa program BLT dana Desa di pekon/Desa Sukoharjo II telah berjalan dengan bagus serta berhasil mengatasi permasalahan yang ada yaitu dengan meringankan keluarga yang terdampak dari covid-19 sehingga program BLT dana Desa ini sangat efektif di terapkan di masa yang sulit seperti ini, walaupun dengan menghilangkan prioritas pembangunan di Desa dengan mengganti setiap programnya untuk penganggaran BLT untuk membantu warga di Desa. Bantuan ini sangat dibutuhkan warga miskin dan keluarga yang terkena dampak langsung dari covid-19 yang kehilangan mata pencaharian. Dengan bantuan tersebut bisa sedikit meringankan beban keluarga untu kehidupan sehari hari. Program tersebut juga mendapatkan respon yang besar dari warga masyarakat terlebih warga yang belum sama sekali mendapatkan bantuan, dan dengan bantuan BLT ini penantian warga dengan bantuan dari pemerintah bisa langsung terdata, karena yang melakukan pendataan dan penetapan adalah pemerintah pekon/Desa Sukoharjo II.

Penelitian ini juga di dukung melalui penelitian yang dilakukan oleh (Maun, 2020) penelitian ini menunjukan efektifitas program BLT dana Desa khususnya bagi masyarakat miskin, bantuan tersebut sangat bermanfaat bagi warga miskin khususnya dan sebagian besar masyarakat mendukung program yang dilakukan oleh pemerintah pusat tersebut. Berdasarkan hal tersebut bantuan BLT dana Desa yang dikeluarkan oleh pemerintah pekon/Desa Sukoharjo bisa dikatakan sangat penting dikeluarkan oleh pemerintah karena membantu secara langsung kehidupan di Desa. Proses yang dilakukan juga sesuai dengan kriteria yang ditetapkan dan pendataan dan penetapan diberikan sepenuhnya kepada pemerintah pekon/Desa, maka kebijakan tersebut bisa berhasil di lakukan dengan baik oleh pemerintah pekon/Desa Sukoharjo II yang mengetahui seluruh seluk beluk kehidupan warga Desanya dalam kehidupan sehari-hari. 


\section{Dampak Kebijakan BLT Dana Desa di Desa Sukoharjo II}

Pemanfaatan BLT dana Desa juga menimbulkan kebingungan dengan penetapan kriteria yang di tetapkan oleh pemerintah pusat, dimana keluarga yang sudah menerima bantun dari pemerintah baik itu PKH, BPNT, BST dari kantor pos tidak di perkenankan untuk mendapatkan bantuan tersebut dan ini menimbulkan polemik di kalangan masyarakat seperti penelitian yang di lakukan oleh (Mufida, 2020), dimana bantuan tersebut juga menimbulkan dampak dan permasalahan sendiri di Desa/ pekon Sukoharjo II.

Dampak yang ditimbulkan dengan adanya program BLT dana Desa akibat adanya pandemi covid-19 membuat pekon/Desa Sukoharjo II harus meniadakan pembangunan fisik untuk menunjang infrastruktur di Desa. Selain itu juga adanya kecemburuan antara warga Desa apabila bantuan BLT dana Desa yang di berikan bisa di bilang telat karena persoalan administrasi, berbeda dengan program BST dari dinas sosial yang diberikan oleh pemerintah melalui dinas sosial yang setiap bulannya warga bisa langsung mengambilnya di kantor post. Berbeda dengan BLT dana Desa yang pengambilannya tidak setiap satu bulan sekali, dan akhirnya menimbulkan ketidaksenangan dan pengaduan kepada pemerintah Desa.

Sedangkan bagi warga yang merasa belum terdata dan tidak mendapatkan bantuan ramai-ramai mendatangi aparat Desa Sukoharjo II dan menanyakan kenapa ia tidak dapat, namun semua itu bisa di jelaskan oleh pemerintah Desa dan dapat dimengerti oleh warga. Kecemburuan warga juga datang dari perluasan bantuan BPNT dan PKH karena perluasan tersebut yang di jadwalkan bulan april sebagai keluarga penerima bantuan BPNT selama 5 Tahun lebih terlambat dalam realisasinya. Karena pembuatan rekening dan ATM keluarga penerima manfaat BPNT/PKH baru terealisasi di bulan juli, yang mana sebelum itu BLT dana Desa terlebih dahulu di tetapkan. Akibatnya banyak warga penerima bantuan perluasan BPNT sebanyak $141 \mathrm{KK}$ yang kondisinya sangat membutuhkan bertanya ke pemerintah Desa karena tidak mendapat bantuan sejumlah Rp.600.000 baik dari BST Dinas sosial yang di kantor post maupun BLT dana Desa dari ATM rekening BRI. Namun penerima BPNT ini bisa terealisasi di bulan juli dengan mendapatkan ATM dan pengambilan beras dan sembako yang di ambil 3 kali sekaligus karena 
keterlambatan dalam realisasi bantuan tersebut, yang sempat mengakibatkan kegaduhan di warga masyarakat karena ketidak sabaran dari warga masyarakat. Pemerintah Desa Sukoharjo II pun sudah memasang daftar setiap bantuan yang ada di papan informasi Desa dan di rumah ketua RT dan Kepala Dusun masing, agar tidak terjadi pertanyaan oleh warga masyarakat.

\section{Kesimpulan}

Berdasarkan hasil penelitian dan pembahasan terhadap evaluasi kebijakan BLT dana Desa pekon/Desa Sukoharjo II maka dapat di ambil kesimpulan bahwa kebijakan yang diambil pemerintah pekon/Desa Sukoharjo II dengan menganggarkan program BLT kepada masyarakat Sukoharjo II sudah tepat dan di evaluasi menggunakan teori Wiliiam N Dunn telah sesuai dan berjalan dengan baik serta mampu mengatasi permasalahan yang ditimbulkan di masyarakat akibat dampak dari covid-19 yang menyebabkan masyarakat miskin dan kehilangan mata pencaharian. Dampak yang ditimbulkan dan menjadi acuan pemerintahan Desa yaitu dengan masih adanya kecemburuan dari warga masyarakat yang lain yang merasa dirinya pantas menerima bantuan namun justru tidak mendapat bantuan.

\section{Referensi}

Ayu, A. A., Siahainenia, R. R., \& Kudubun, E. E. (2020). Prioritas Penggunaan Dana Desa Jekawal Kabupaten Sragen Di Era Pandemi Covid-19. Jurnal Analisa Sosiologi, 9(2), 551-566. https://doi.org/10.20961/jas.v9i2.43738

Ikbal, M. (2015). Evaluasi Kebijakan Penertiban Ternak Di Kecamatan Parigi Kabupaten Parigi Moutong. Katalogis, 3(10), 167-172.

Kurnia, U. E., \& Widhiasthini, N. W. (2021). Evaluasi Kebijakan Padat Karya Tunai Pada Pengelolaan Dana Desa Dalam Pemberdayaan Masyarakat Desa Dalam dokumen Rencana Pembangunan Jangka Menengah Nasional 2015-2019 5, 148-161.

Maun, C. E. F. (2020). Efektivitas Bantuan Langsung Tunai Dana Desa Bagi Masyarakat Miskin Terkena Dampak Covid-19 Di Desa Talaitad 
Kecamatan Suluun Tareran Kabupaten Minahasa Selatan. Jurnal Politico, 9(2), 1-16.

Mufida, A. (2020). Polemik Pemberian Bantuan Sosial Di Tengah Pandemic Covid 19. ADALAH Buletin Hukum \& Keadilan, 4(1), 159-166.

Sartika, I. (2011). Evaluasi Kebijakan Pemberdayaan Nelayan. JIANA ( Jurnal Ilmu Administrasi Negara ), 11(2), 111-124. Retrieved from http://ejournal.unri.ac.id/index.php/JIANA/article/view/592

Subarsono, AG. (2011) Analisis Kebijakan Publik (Konsep, Teori dan Aplikasi), Yogyakarta: Pustaka Pelajar

Sugiyono. (2010). Metode Penelitian Kuantitatif, Kualitatif dan R\&D. Bandung: Alfabeta.

Taufiqurkhman. (2014). Kebijakan Publik. Kebijakan Publik, 171. Retrieved from ISBN:602-9006-07-D 